\title{
France, Football and Society
}

\author{
DAVID HAND
}

Manchester Metropolitan University

Bromberger, C., Football, la bagatelle la plus sérieuse du monde (Bayard, 1998), 137 pp., 80F., ISBN 2227137584.

Mignon, P., La Passion du football (Odile Jacob, 1998), 287 pp., 130F., ISBN 2 783106110.

Ravenel, L., La Géographie du football en France (PUF, 1998). 143 pp.. 98F., ISBN 213049403 X.

Academic interest in football is a relatively recent phenomenon in France but one which has undoubtedly been given fresh impetus by the double success of the 1998 World Cup finals. Despite disquiet in certain quarters about the ticket allocation, the organisation and running of the finals by the French hosts were generally praiseworthy, presented a largely positive image of France to the world and offered, according to Dauncey and Hare, 'a statement of national political and economic self-confidence'. ${ }^{1}$ Also, of course, the fact that the host nation was the ultimate winner of the tournament helped raise even further the profile of football in France and guaranteed its place of pre-eminence in the growth area of academic enquiry that is popular culture. The three works under review were, for sound commercial reasons, all published in the period immediately before the World Cup finals. Two of the texts are written by established scholars (Bromberger and Mignon) whilst the third signals the entry into the field of a new researcher (Ravenel). All three demonstrate not only the burgeoning of interest in football in French academic circles but also the increasing diversification of the study itself. In this sense, the French are, if a little belatedly, following the same trajectory as their British homologues. Focusing initially on the historical aspects of the sport's development and then on its 'hooligan' problem. ${ }^{2}$ French academics arc now studying football from a multiplicity of perspectives and the three authors under consideration here, an ethnologist, a sociologist and a geographer, are amongst the foremost examples of this new, diverse and welcome trend.

Professor of ethnology at Provence University, Christian Bromberger has applied the rigorous methods of his discipline to the study of football supporters in Marseille, Lens, Naples, Turin and Teheran. Football, la bagatelle la plus sérieuse du monde repeats some information from the author's earlier, 
ground-breaking Le Match de footbal/' but also usefully contains new material, notably on Lens, and updated information on Marseille. Through extensive fieldwork involving questionnaires, interviews, videos and analyses of supporters' banners and chants, Bromberger seeks to understand what makes a football match so captivating to watch and to discuss. He concludes that the drama generated by what is essentially a simple game arouses partisan passions which highlight the fundamental issues of postmodern society: identity, gender and race. 'Telle est la leçon surprenante que m'ont livrée des mois d'enquête passés debout dans les tribunes', recounts Bromberger (p. 10) as he discovers that football is 'Une bagatelle pleine de sens, en somme' (p. 136). After dismissing in chapter 1 those who fail to understand the full significance of football by erroneously considering it variously as the opium of the masses, a collective regression to savagery or the domain of only one social group, Bromberger goes on to demonstrate, in the next two chapters, how football reflects society's dominant values and structures. Of considerable interest here is the exploration of the ways in which this sport is an arena for the affirmation of national, regional and local identities. The well attested rivalries between Marseille and Paris, and Lens and Lille are revisited but with the added benefit of fresh data gathered from empirical fieldwork. Similarly. French supporters' impressions of the style of play of their favourite teams are recounted in an accessible way: Lensois, for instance, apparently favour the virtues of solidarity, courage and hard work whilst Marseillais see in their team's supposedly spectacular panache and virtuosity a reflexion of their own beliefs about the identity of the city of Marseille itself. Bromberger's fourth chapter presents the findings from his research into football match crowds and has revealing things to say about the sociology of spectators: French supporters are predominantly young (70 per cent under 35) but France, despite some progress, still lags behind other European countries in attracting women to football who constitute only 7 - 14 per cent of a typical crowd with those women who do attend finding themselves submerged in a male-dominated culture; 4 the 'working class' are proportionally under represented, too, but the presence of supporters from ethnic minorities varies from the negligible (Paris) to cases where the percentage reflects that of the population of the city as a whole (Marseille).

Turning to the second book under review. Patrick Mignon's LA Passion du football covers similar ground to Bromberger's with its examination of the origins of football and its universal appeal as well as with the assertion that 'le 
match de football dit quelque chose d'essentiel sur les sociétés dans lesquelles il prend place et renvoie à des enjeux qui dépassent le cadre du match lui-même' (p. 15). Mignon is interested in the ways in which football may be seen as an extension of society's structures whether these are social, cultural, political or economic but his work differs from Bromberger's in certain respects: the main country chosen to contrast with France here is not Italy but England (although rather too much emphasis is placed on the 'hooligan' question in the four chapters devoted to the English game); also the principal case study in the analysis of French football culture is not Marseille but their arch rivals Paris Saint-Germain; finally Mignon devotes more space to the economic issues and the increasing commercialisation of football in France. Football is clearly now 'un sport qui tend à devenir un vrai business' (p. 80) as big firms seize the opportunities it offers for marketing and profit. This movement, however, is not all one way. As Noel Le Graët, President of the Football League noted in Le Monde (8 août 1998), 'Les grandes entreprises sont de plus en plus nécessaires dans le football de haut niveau' as French clubs are no longer allowed by law to receive local authority subsidies. One of the biggest investors in football, as Mignon demonstrates, is television the money from which is distributed equally amongst the clubs and which now typically provides 25 per cent of their income in return for broadcasting over 500 hours of football per year (a staggering increase on the 10 hours per year of the mid-1970s). The transformation of football into a commercialised form of show business has not, however, prevented other more positive developments in the French game such as the gradual increase in participation as spectators and players of women and people from ethnic minorities. Indeed, the presence of ethnic minority players in the national team — condemned by the extreme Right - has added fuel to the fires of the debate over national identity. With remarkable prescience, Mignon noted: 'Dans un tel contexte, ce ne serait peut-être pas si mal de gagner une Coupe du Monde, surtout avec des joueurs qui s'appellent Zidane, Karembeu, Thuram' (p. 264). This theme was expounded at length and at large when France's squad of blacks, blancs, beurs duly won the World Cup with the national team being portrayed by Le Monde for instance, as 'cette équipe multiethnique (...) le symbole de la diversité et de l'unité du pays' (18 juillet 1998) testifying once again to the validity of Mignon's affirmation that football is not a world apart but a reflexion of the society in which it is played.

Finally, Loïc Ravenel's La Géographie du football en France is an extract from his Avignon University thesis. As such, it is extensively referenced, copiously illustrated with maps, charts and diagrams and divided into 
intricately numbered sub-sections. The analysis itself is prompted by two questions. Why do French cities - unlike their European counterparts - rarely, if ever, have more than one top flight football team? For instance, London, Birmingham and Greater Manchester have 13 teams in the top two divisions this year whilst Paris, Lyon and Marseille, France's three biggest combinations, can muster only four. Second, how are clubs from small cities in France able to compete successfully with their big city neighbours? To update Ravenel's data, in the last five years, the championship has been won by a major conurbation only once (Paris Saint-Germain, 1994) with smaller cities' teams winning in 1995 (Nantes), 1996 (Auxerre), 1997 (Monaco) and 1998 (Lens). To answer these questions, Ravenel divides his work into three sections. First, he outlines the spatial distribution of top flight football demonstrating that it is essentially an urban and national phenomenon. Unlike rugby or basketball, football has conquered the whole of France with most of the principal population centres having a team in one of the top divisions. It would be erroneous, though, to assume that football in France is always associated with big industrial cities as Ravenel's analysis demonstrates. Ravenel then takes a historical perspective in his second section to examine the phases in the development of the sport in France. The first professional championship was held in 1932 and encompassed the oldest clubs located in the north, the east and the south east (e.g. Paris, Lille, Marseille, Sète). Between 1970 and 1993, the second division was opened to amateur clubs prompting an expansion of top-flight football into the smaller towns of central and western France (e.g. Auxerre, Guingamp). The third section of the book describes the part played by local authorities in funding football clubs which, along with the method of distributing television money outlined above, is seen as a determining factor in the tendency for French cities to have only one club and for small city clubs to be as successful as the conurbations. Most football stadia are owned by local authorities and even in the late 1990s on average 11 per cent of clubs' incomes was provided by local authority funding. ${ }^{5}$ Local authorities would not fund more than one club in their area as to do so would not only splinter their budget but also inadvertently fund local tensions and antagonisms instead of supporting regional consensus. To promote this sense of community, local authorities have proved adept at using football to project their own regional identities which are, in turn, reiterated by the spectators themselves and by media sports journalists commenting on football. Three case studies follow to support the hypothesis: Bastia ('la spécificité corse'), Guingamp ('l'élite à la campagne') and Auxerre ('le bon sens paysan'). Football in France may be seen, then, as a spatial extension of that country's urban development and of its politico-administrative philosophy (State involvement in sport as a public service) and structures (the promotion of 
regional identities via local authority action).

We have seen that in a country which has had its affection for football rekindled both by staging the World Cup finals and by winning its first major tournament since 1984, academic interest in the sport itself is continuing to grow. Furthermore, this interest is diversifying as football attracts the attention of researchers working in a wide range of disciplines from ethnology to geography and from history to sociology. Most importantly, the three texts under review all highlight, from their different perspectives, the central issue of how football reflects social structures and identities and it is, indeed, this very issue which will prove to be a source of much debate in the ever expanding study of what is, after all, the most popular sport on the planet and a vibrant element of French popular culture.

Notes and references

1. DAUNCEY, H. and HARE, G., 'Sport, culture and society in modem France', Modern and Contemporary France, 6 (1998). p. 287.

2. E.g. WAHL. A . Les Archives du football. Sport et société en France 1880-1980 (Gallimard/Julliard. 1989) and BROUSSARD, P. Génération supporter (Laffont, 1990) respectively.

3. BROMBERGER, C., Le Match de football. Ethnologie d'une passion partisane à Marseille, Naples et Turin (Maison des sciences de l'homme, 1995).

4. For more on this issue, see DUKE, V. and CROLLEY, L., Football, Nationality and the State (Longman, 1996), ch, 9.

5. In France, football, in common with other sports, is invested with the status of public service by the State which delegates its mission in this respect to the football authorities. Local authority funding on this scale (until the recent law change) is, then, entirely consistent with this philosophy.

6. The European Championship finals, also held on French soil. 